\title{
Fish Feces as Fish Food on a Pacific Coral Reef
}

\author{
D. Ross Robertson \\ Smithsonian Tropical Research Institute, Apartado 2072, Balboa, Republic of Panama
}

\begin{abstract}
The fates of 5,975 feces produced by 88 species of reef fishes were monitored at Palau (western Pacific Ocean). At least 45 fishes ate fish feces in addition to other foods. Intraspecific coprophagy and autocoprophagy were very rare and most coprophagous interactions were between members of different trophic groups. Fecal material moved through a feeding network of fishes, from carnivores to herbivores with low carbonate diets (LCDs) of fleshy (principally red) microalgae to herbivores with LCDs of brown macroalgae to high carbonate diet (HCD) herbivores and detritivores. Intermediate links were often omitted. This network retained food material entering it, and, because herbivores ate piscivore feces, appeared to recycle some food. Fishes ate almost all the feces of zooplanktivores and other carnivores, and most of the feces produced by herbivores with LCDs of microalgae and by coralivores with LCDs of hard-coral tissue. Fishes ate few feces of LCD herbivores that fed on brown macroalgae and virtually no feces of herbivores and detritivores with HCDs. A few fishes regularly associated with local concentrations of zooplanktivores and LCD microalgivores and consumed large amounts of the feces the latter produced. Although coprophagy is a common feeding tactic its importance to the 'average' members of the fish community is unknown.
\end{abstract}

\section{INTRODUCTION}

That feces produced by marine macroinvertebrates and fishes contain sufficient organic matter to represent a usable food source for macroscopic animals is supported by the observation that, in no-choice situations in the laboratory, detritus feeding animals of various phyla eat such feces (Johannes and Satomi, 1966; Frankenberg and Smith, 1967; Frankenberg et al., 1967). Johannes and Satomi (1966) showed that one marine crustacean will eat and absorb material from its own feces. Direct observation of coprophagy in the field and a determination of its relation to the general feeding activity of marine macroorganisms are lacking. The only attention directed to fish feces on coral reefs concerns the production of calcareous material by various herbivores that feed by scraping coralline substrates or consuming calcareous algae, and carnivores that ingest calcareous animal fragments (Cloud, 1959; Bardach, 1962; Glynn et al., 1972; Smith and Paulson, 1974; Ogden, 1977; Frydl and Stearn, 1978; Scoffin et al., 1980). I have found only 2 incidental and anecdotal references to the consumption of fish feces by fishes (Barlow, 1975; Moyer and Nakazono, 1978).

Coprophagy is not mentioned in the most comprehensive studies available of the diets and feeding activity of reef fishes (Hiatt and Strasburg, 1960; Randall, 1967; Jones, 1968; Hobson, 1974, 1975; Hobson and Chess, 1978). Here I present information demonstrating that ingestion of fish feces is a common behavior among fishes on one western Pacific reef, and suggesting that such coprophagy may be a significant ecological process on that reef. This study addresses the following questions: What types of fish feces are eaten by fishes in different trophic groups? How many of the feces produced by fishes of different trophic groups are eaten by fishes? How important can coprophagy be to some species that practice it? Besides the diet of its producer, what factors have a role in determining whether a particular feces is eaten by a fish?

\section{METHODS}

Data were collected from January through April 1980 at Palau (western Caroline Islands, Pacific Ocean, Latitude $7^{\circ} 30^{\prime} \mathrm{N}$, Longitude $134^{\circ} 30^{\prime} \mathrm{E}$ ). Most diving was done along a $1.5 \mathrm{~km}$ stretch of reef that runs southwest from the lighthouse marking the eastern channel entrance to Malakal harbor, Koror. Most observations were made within $25 \mathrm{~m}$ of the outer edge of the reef, although the intertidal reef flat, which is up to $0.75 \mathrm{~km}$ 
wide, was also sampled intermittently. A few data were gathered on a lagoon patch reef that bordered one of the branches of the channel system of the Malakal harbour entrance. Observations were made (while snorkelling) on fishes living in water less than $10 \mathrm{~m}$ deep.

I collected data on the fates of feces of fishes in 5 trophic groups: (1) Zooplanktivores: These included 4 fusiliers (Lutjanidae), 8 damselfishes (Pomacentridae), 2 wrasses (Labridae), 1 goby (Gobiidae) and 2 surgeonfishes (Acanthuridae). (2) $\mathrm{Herbivores:} \mathrm{Fishes} \mathrm{that} \mathrm{fed} \mathrm{on} \mathrm{benthic} \mathrm{algae} \mathrm{and}$ detritus included 12 surgeonfishes, 19 parrotfishes (Scaridae), 6 rabbitfishes (Siganidae), 1 triggerfish (Balistidae), 1 filefish (Monacanthidae), 1 chub (Kyphosidae) and 2 damselfishes. These herbivores were subdivided into 3 trophic groups. Two groups of species with low carbonate diets (LCDs) ingested little calcium carbonate and produced dark, slow-sinking feces. These included (a) 9 species of microalgivores, which fed on small filiform and fleshy, principally red algae; (b) 8 species of macroalgivores, which ate mainly large, principally brown algae. The remaining 26 species had high carbonate diets (HCDs) and produced pale, heavy, calcareous feces. They ate detritus, cropped microalgae, and scraped and bit off pieces of coralline rock. (3) Corallivores: Fishes that ate live corals included 7 butterfly fishes (Chaetodontidae) and one damselfish.

Data on fecal fates were collected both by following and observing selected individuals of various species and from incidental observations. Notes were made of the height above the substrate of the release of the feces, its size, shape, consistency, and sinking rate, whether it was inspected, tasted, eaten or rejected by a fish and hit the bottom. Reactions of nearby fish to the defecation and feces were noted. No data were collected if the defecator or potential coprophages in its vicinity were obviously reacting adversely to the observer.

Estimates of the volume of feces produced per defecation by 3 species (Chromis atripectoralis, a fusilier and a dussumierid) were made by pipetting fresh feces out of the water column, and immediately preserving them in $10 \%$ neutral, buffered formalin. For each species examined, 1 feces was collected from each of 25 different individuals. Each entire sample was shaken vigorously to break up the feces, centrifuged for 1 min, and the resultant volume divided by 25 to give an average feces volume per defecation.

Data on the diets of defecators were obtained from 3 sources: (1) Stomach contents were examined of the 5 acanthurids listed in Table 5 and of all species listed in Table 4 (Robertson and Gaines, in prep.) except the 2 damselfishes and the siganid Siganus punctatus. (2) A series of 10 -min observations was made on the feeding behavior of individuals of each species of corallivorous chaetodon ( $\mathrm{n}=23-31$ observation periods/species). During each observation period the number of bites that the subject fish took from different types of substrates were recorded. The stomach contents of the chaetodon Chaetodon trifasciatus and the corralivorous damselfish Plectroglyphidodon dickii were examined. (3) The literature was examined for accounts of diets at the species, genus, and family level (Randall, 1955; Fowler, 1959; Hiatt and Strasburg, 1960; Randall and Brock, 1960; Munro, 1967; Helfrich et al., 1968; Randall and Klausewitz, 1973; Hobson, 1974; Allen, 1975; Hobson, 1975; Reese, 1975; Hobson and Chess, 1977; Allen 1979; Lassuy, 1980; Lobel, 1980; Randall, 1980).

\section{RESULTS}

\section{Amounts of Different Types of Fish Feces Eaten by Fishes}

\section{Feces of Zooplanktivorous Fishes}

All zooplanktivores studied actively produced feces while they were feeding up in the water column. They defecated at much lower rates when they were travelling or resting close to the substrate. Feces produced by zooplanktivores were of low density. They sank very slowly and sometimes spent up to 5 min or more in the water column and moved in excess of $50 \mathrm{~m}$ laterally before being eaten or reaching the substrate.

There were 4 classes of zooplanktivorous fishes with respect to the distance from the substrate at which they fed on plankton.

(1) Large mixed species schools of fusiliers ranged back and forth along the outer edge of the reef as the tide flooded. They fed in the middle and upper levels of the water column at distances of up to $30 \mathrm{~m}$ or more off the edge of the reef in water depths of up to at least $15 \mathrm{~m}$. Coprophages ate virtually all (99\%) of the feces that the fusiliers produced at this time (Table 1). One surgeonfish commonly ranged as far off the reef as the fusiliers. This species ate benthic algae as well as plankton. Most (75\%) of its feces that were observed were eaten by coprophages (Table 1).

(2) Four damselfishes and 1 labrid, all abundant in the study area, fed in large multi- and monospecific schools at the outer edge of the reef as the tide flooded. They fed throughout the water column and ranged up to about $7 \mathrm{~m}$ from the substrate. Other fishes ate $70-90 \%$ of the feces they produced, as well as $91 \%$ of the feces produced by another labrid (Thalassoma hardwickei) that fed both with those midwater feeding schools and also on the substrate (Table 1). The great 
feces (Table 6). Very few $(5 \%)$ of the feces of one damselfish (Plectroglyphidodon dickii) that ate both coral and microalgae were eaten (Table 6).

A number of the corrallivorous chaetodons formed heterosexual pairs. Both members of pairs of Chaetodon trifasciatus frequently defecated together: 20 of 59 defecations consisted of the members of a pair defecating within $10 \mathrm{~s}$ of each other. As individuals of this species defecated about once $\mathrm{h}^{-1}(\mathrm{n}=24 \times 10 \mathrm{~min}$ observations), those pair defecations were not chance events (Fisher exact probability, $p=0.0035$; the expected number of observations $=$ chance that one defecation will be followed by another with $10 \mathrm{~s}=49$ / 360 ; observed $=10$ out of 49 . For the calculation of the expected number was taken to $=1$ ). Coprophages frequently approached pairs of $C$. trifasciatus as they moved along above the substrate and remained with them after one member of the pair defecated.

Corallivorous chaetodons rarely defecated while feeding and most of them defecated when moving well

Table 5. Fates of feces produced by herbivorous fishes (with high carbonate diets) in Palau

\begin{tabular}{|c|c|c|c|}
\hline \multicolumn{2}{|r|}{ Defecator } & \multirow{2}{*}{$\begin{array}{l}\text { Proportion of feces eaten } \\
\text { by coprophagous fishes }\end{array}$} & \multirow[b]{2}{*}{ No. feces } \\
\hline Diet & Species (Family) ${ }^{1}$ & & \\
\hline MICROALGAE, & Acanthurus auranticavus" (Ac) & .11 & 66 \\
\hline \multirow[t]{6}{*}{ DETRITUS } & A. nigricaudus* (Ac) & .00 & 91 \\
\hline & A. olivaceus (Ac) & .00 & 16 \\
\hline & A. maculiceps ${ }^{*}(\mathrm{Ac})$ & .00 & 23 \\
\hline & Ctenochaetus striatus" (Ac) & $\ll .01$ & 247 \\
\hline & ? Amanses scopas* (Mn) & .13 & 8 \\
\hline & Dischistodus perspicillatus" (Pm) & .00 & 25 \\
\hline $\begin{array}{l}\text { ENDOLITHIC } \\
\text { and }\end{array}$ & 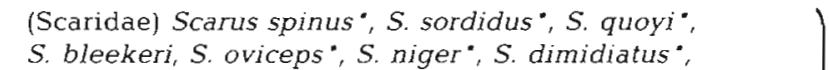 & & $\begin{array}{c}11-180 \\
\text { per species }\end{array}$ \\
\hline EPIPHYTIC & S. rivulatus", S. gibbus", S. psittacus", S. chlorodon", & .00 & Total 1276 \\
\hline ALGAE & $\begin{array}{l}\text { S. japanensis, S. frenatus ", S. festivus, S. schlegeli }{ }^{*}, \\
\text { S. rubroviolaceus, Cetoscarus bicolor, Hipposcarus harid }{ }^{*}, \\
\text { Bolbometopon muricatus }\end{array}$ & & \\
\hline \multicolumn{4}{|c|}{$\begin{array}{l}\text { Ac: Acanthuridae, Mn: Monocanthidae, Pm: Pomacentridae } \\
\text { - Coprophagous species, which also included Acanthurus pyroferus (Ac) } \\
\text { ? some uncertainty as to diet. }\end{array}$} \\
\hline
\end{tabular}

Table 6. Fates of feces produced by corallivorous fishes in Palau

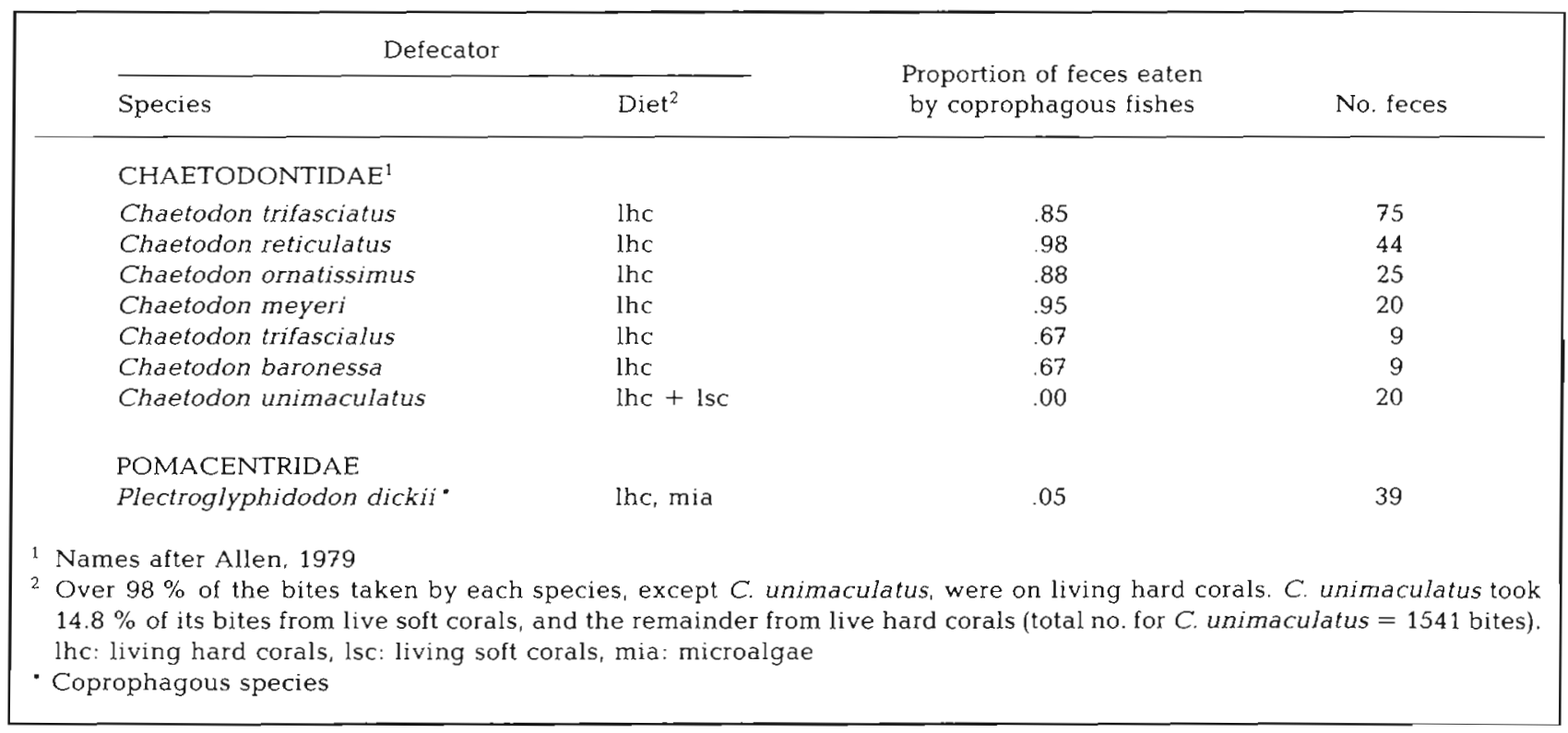


above the substrate. Only 2 of 170 defecations by 6 species that ate only hard-coral tissue occurred while the fish was feeding, and 149 of them occurred while the fish was more than $25 \mathrm{~cm}$ above the substrate.

\section{Coprophagous Interactions Between and Within Trophic Groups}

Fig. 1 summarizes coprophagous relationships at the level of trophic groups. Coprophagy was practiced by at least 45 species of fishes (Tables 1-6). Most were herbivores, although representatives of all but one (the piscivores) of the other major trophic groups were included. The following patterns were found.

(1) Feces of zooplanktivorous fishes were consumed mainly by herbivorous fishes, principally those with LCDs of microalgae, and, to a lesser extent, macroalgae. Also, 6 species of zooplanktivorous damselfishes that fed close to the substrate (Pomacentrus pavo, P. popei, P.bankanensis, P. emarginatus, Glyphidodontops cyaneus, and Amblyglyphidodon ternatensis) were repeatedly observed feeding on the feces of zooplanktivores that fed further away from the substrate (Chromis spp. and Thalassoma amblycephalus). Those 6 species accounted for only a small percentage of the zooplanktivore feces that were eaten by fishes (Fig. 1).

(2) Feces of carnivorous fishes were almost all eaten by herbivorous fishes, principally those with LCDs of microalgae. Two cases of carnivorous fishes eating the feces of other carnivores were noted: the labrid Coris variegata and the balistid Balistapus undulatus ate feces of the nemipterid Gnathodentex aurolineatus and the labrid Epibulus insidiator respectively. In both cases the defecator and the coprophage fed on invertebrates.

(3) Excreta of fishes with LCDs that ate benthic microalgae were eaten mainly by herbivores with HCDs but also by those with LCDs that ate macroalgae. In addition, appreciable amounts of those feces were eaten by several fishes with LCDs of microalgae (Fig. 1). Two species, Kyphosus sp. and Melichthys vidua, accounted for $45 \%$ and $48 \%$ respectively of the coprophagous interactions between members of this trophic group. Kyphosus sp. might better be assigned to the LCD macroalgivore group because much of the microalgal material in the stomachs of the specimens examined may have been from microalgivore feces. Similarly, much of the contents of $M$. vidua stomachs may have been microalgivore feces and $M$. vidua may belong in another trophic group.

(4) Only herbivores with HCDs ate the feces of fishes that had LCDs of macroalgae.

(5) Only one instance of a fish eating its own feces (autocoprophagy) was observed, and that was probably accidental: an acanthurid (Acanthurus glaucoparieus) feeding on feces being produced by a school of zooplanktivores ate 1 of its own feces. I never saw a fish eat the feces of another conspecific.

Coprophagic interactions between members of different trophic groups are indicated as species/species

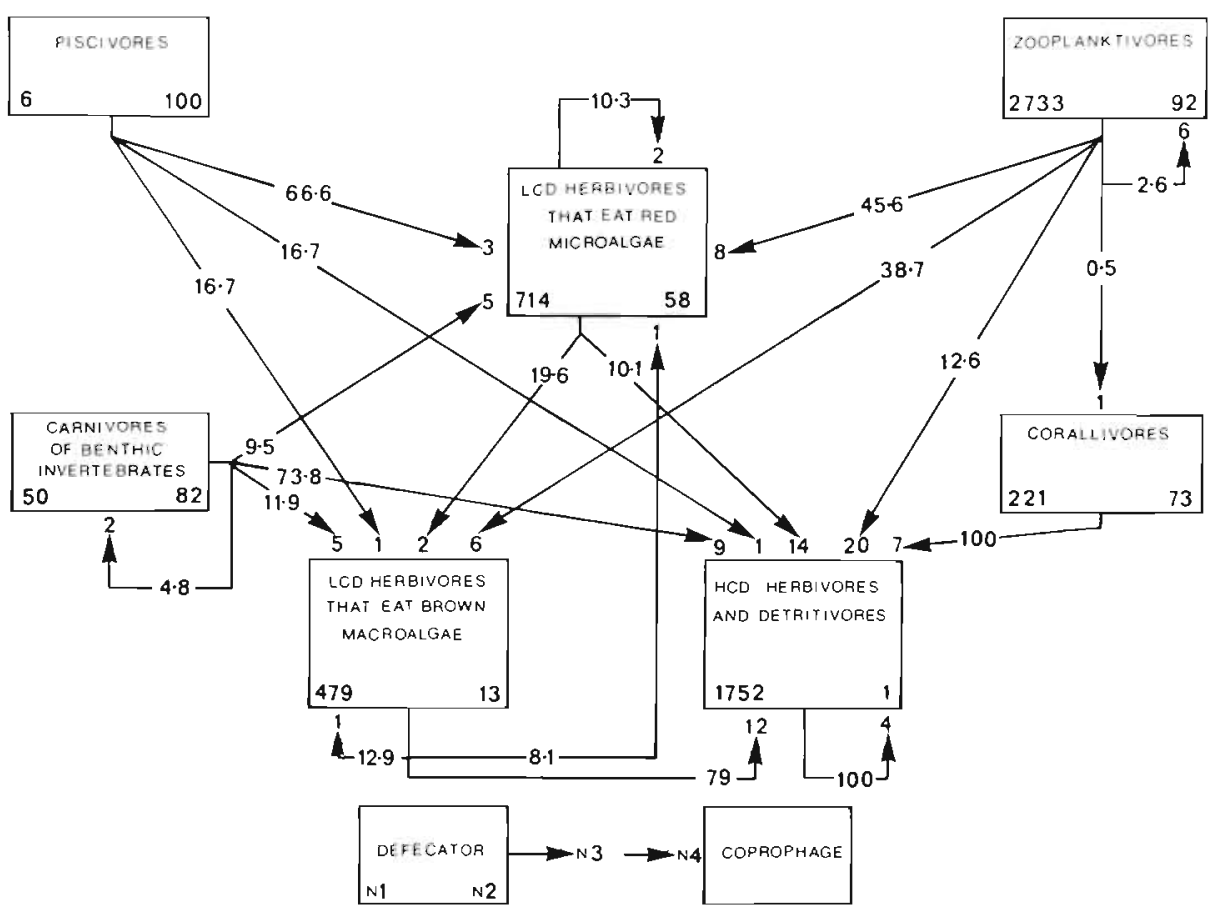

Fig. 1. Coprophagic relations among Palauan fishes. Herbivores: $\mathrm{LCD}=$ low carbonate diet. $\mathrm{HCD}=$ high carbonate diet. Key: $\mathrm{n}_{1}=$ total number of feces observed being produced by that class of defecator, $n_{2}=$ percent of feces that were eaten by all coprophages, $\mathrm{n}_{3}=$ percent of feces eaten that were eaten by a particular class of coprophage, $\mathrm{n}_{4}=$ number of species of a particular trophic group that ate feces from that class of defecator. Corallivores do not include species that fed on soft corals 
interactions in Fig. 2. Large amounts of material ingested by zooplanktivores at the reef edge may have passed through the guts of 3 species of fishes, because $44.4 \%$ of zooplanktivore feces were eaten by 6 LCD microalgivores and most of the latter's feces were in

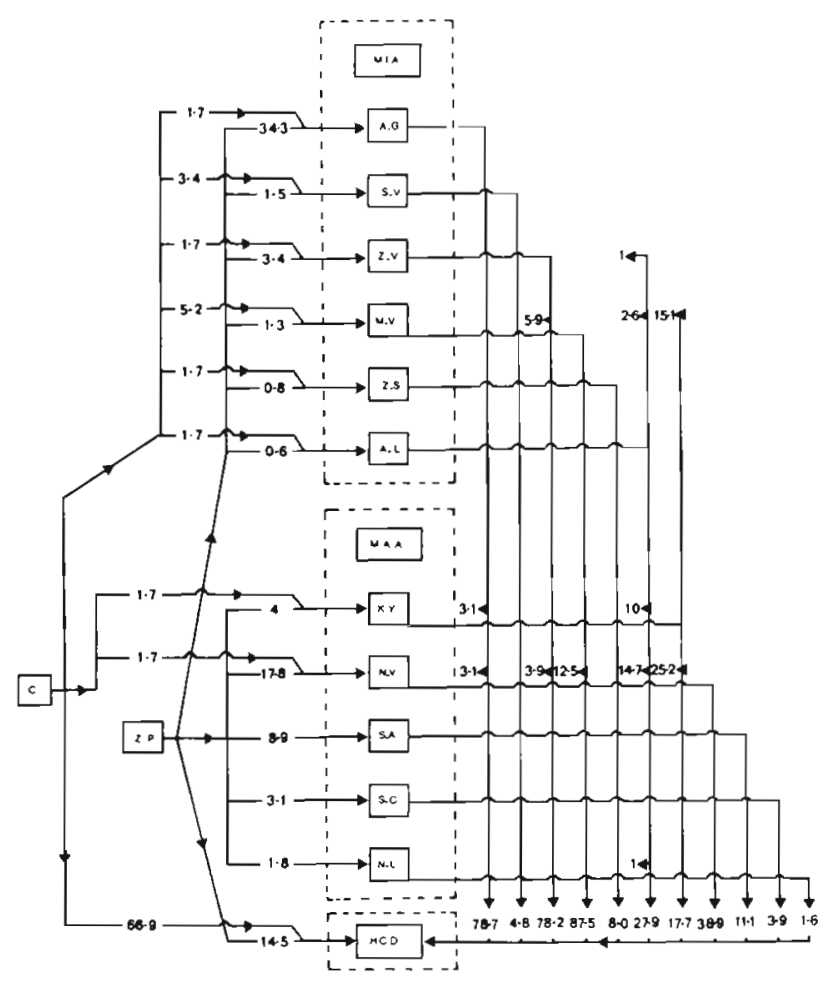

Fig. 2. Coprophagic interactions between Palauan fish species belonging to different trophic groups. Trophic groups: $\mathrm{C}=$ nonplanktivorous carnivores; $\mathrm{ZP}=$ zooplanktivores, MIA $=$ microalgivores with low carbonate diets-AG $=$ Acanthurus glaucoparieus, $\mathrm{Ky}=$ Kyphosus sp., ZV = Zebrasoma veliferum, $\mathrm{MV}=$ Melichthys vidua, $\mathrm{ZS}=$ Zebrasoma scopas, $\mathrm{AL}=$ Acanthurus lineatus $; \mathrm{MAA}=$ macroalgivores with low carbonate diets-NV = Naso vlamingii, $\mathrm{SA}=$ Siganus argenteus, $\mathrm{SC}=$ Siganus corallinus, $\mathrm{NL}=$ Naso lituratus, $\mathrm{SV}=$ Siganus vulpinus; $\mathrm{HCD}=$ herbivores and detritivores with high carbonate diets. Arrows indicate direction of flow of ingested feces. Each number represents the percentage of all feces produced by a particular trophic group that were eaten by the particular species or group of coprophage

turn eaten by LCD macroalgivores and HCD herbivores and detritivores. The most usual of these 3 species pathways was the zooplanktivore / Acanthurus glaucoparieus / HCD herbivore and detritivore path. Small amounts of material eaten by nomplanktivorous carnivores may have been involved in similar 3 species chains, because $13.7 \%$ of those carnivores feces were eaten by the same LCD microalgivores that ate zooplanktivore feces. Still smaller amounts of food eaten by zooplanktivores and carnivores may have passed through 4 species' guts, principally along the pathway involving LCD microalgivores, Naso vlamingii, and HCD herbivores and detritivores. The maximum number of links in any of these 'food chains' was 6 , although the amounts of material that passed the full length of such a chain must have been exceedingly small.

\section{Associations Between Coprophagic Fishes and Producers of Feces}

A number of herbivorous fishes practiced coprophagy repeatedly and predictably, and regularly associated with producers. Four types of associations were observed.

(1) Seven species belonging to 5 families (Table 7) consistently joined schools of zooplanktivores that fed at the shallow front of the reef during flood tides. They also joined similar schools feeding on eggs of spawning labrids, scarids and acanthurids that migrated in large numbers to the outer edge of the reef during the first $2-3 \mathrm{~h}$ of the ebb tide (Robertson and Foster, in prep.). Those coprophages included both territorial, nonterritorial and schooling species.

(2) Three surgeonfishes (Zebrasoma veliferum, Acanthurus auranticavus and $Z$. scopas) with diets of microalgae each formed feeding schools of 50-100 individuals and fed in the territories of various damselfishes in intertidal and subtidal areas. Those schools were commonly joined by various parrotfishes. Scarus rivulatus, S. chlorodon and Hipposcarus harid joined schools of $Z$. veliferum and $A$. auranticavus, while $S$. oviceps, $S$. festivus and $S$. sordidus joined those of $Z$. scopas. The parrotfishes not only fed in the damselfish territories with the surgeonfishes, but also actively sought out and ate feces produced by the schooling surgeonfishes.

(3) Two surgeonfishes with LCDs of microalgae, Acanthurus glaucoparieus and A. lineatus, commonly held feeding territories along the outer edge of the reef. The territories of both invariably overlapped those of the surgeonfish Ctenochaetus striatus, which had an LCD of detritus. Ctenochaetus striatus also consumed $42 \%$ of $A$. glaucoparieus feces eaten by fishes, and $37 \%$ of those of $A$. lineatus eaten.

(4) The territories of Acanthurus lineatus typically were aggregated (unpubl. own data), and the species formed colonies of up to about 100 individuals at the outer edge of the intertidal portion of the reef. Three coprophages, Naso vlamingii, Kyphosus sp., and Melichthys vidua, characteristically were observed around the edges of and in the water column above the colonies of $A$. lineatus. Those 3 species accounted for $22 \%, 20 \%$ and $8 \%$, respectively, of the feces of A. lineatus eaten by fishes. 
Table 7. Accompaniment of schools of actively feeding zooplanktivorous fishes by coprophagous fishes in Palau

\begin{tabular}{|c|c|c|c|c|c|c|}
\hline \multicolumn{3}{|c|}{ Coprophage $^{1}$} & \multicolumn{4}{|c|}{ Percent of schools accompanied by each species of coprophage } \\
\hline & & & \multicolumn{2}{|c|}{ Abudefduf/Chromis/Thalassoma schools } & \multicolumn{2}{|c|}{ Fusilier schools } \\
\hline Species & $\left(\right.$ Family $\left.{ }^{2}\right)$ & Sociality ${ }^{3}$ & Flood tide 4 & Ebb tide 5 & Flood tide ${ }^{4}$ & Ebb tide ${ }^{5}$ \\
\hline Acanthurus glaucoparieus & $(\mathrm{Ac})$ & IT & 51 & 75 & 0 & 27 \\
\hline Naso vlamingii & (Ac) & $\mathrm{R}$ & 39 & 2 & 61 & 29 \\
\hline Melichthys vidua & (B1) & $\mathrm{R}$ & 33 & 9 & 0 & 4 \\
\hline Kyphosus sp. & (Ky) & $S, R$ & 20 & 8 & 16 & 29 \\
\hline Siganus argenteus & $(\mathrm{Sg})$ & $\mathrm{S}$ & 8 & 0 & 32 & 4 \\
\hline Zebrasoma veliferum & (Ac) & $T, S$ & 6 & 4 & 7 & 3 \\
\hline \multirow[t]{2}{*}{ Hipposcarus harid } & (Sc) & $\mathrm{R}, \mathrm{S}$ & 0 & 0 & 13 & 0 \\
\hline & & n schools & 132 & 197 & 31 & 203 \\
\hline \multicolumn{7}{|c|}{$\begin{array}{l}1 \text { Only species of coprophages that accompanied } \geqslant 5 \% \text { of at least } 1 \text { class of school included } \\
2 \text { Ac: Acanthuridae, Bl: Balistidae, Ky: Kyphosidae, Sg: Siganidae, Sc: Scaridae } \\
3 \text { Sociality: IT: inter-and intraspecifically territorial, T: intraspecifically territorial, S: schooling, R: roaming, apparently non- } \\
\text { territorial and non-schooling } \\
4 \text { Aggregations which fed in incoming water mass at or near outer edge of reef } \\
5 \text { Aggregations that formed at freshly spawned planktonic eggs of labrids, scarids and acanthurids at reef edge }\end{array}$} \\
\hline
\end{tabular}

\section{Amounts of Feces Ingested by Two Fishes Actively Associating with Producers}

I made the following estimate of the amounts of feces eaten by 2 surgeonfishes that associated with zooplanktivores eating the eggs of spawning fishes (see above). Individual Acanthurus glaucoparieus ate $6 \pm 2.3$ (mean $\pm 95 \%$ CI) fusilier feces $+7 \pm 4.9$ Chromis feces $1 / 4 \mathrm{~h}^{-1}(\mathrm{n}=13)$ while individual Naso vlamingii ate $50 \pm 15.8$ fusilier feces $1 / 4 \mathrm{~h}^{-1}(\mathrm{n}=12)$. The average volumes of a fusilier and a Chromis feces were $0.072 \mathrm{~cm}^{3}$ and $0.024 \mathrm{~cm}^{3}$, respectively ( $\mathrm{n}=25$ each). Over a 2-h spawning period, an A.glaucoparieus would consume about $5 \mathrm{~cm}^{3}$ of such feces while an $N$. vlamingii would ingest about $29 \mathrm{~cm}^{3}$. Representative specimens of both surgeonfishes speared in the study area weighed $100-150 \mathrm{~g}$. Zooplanktivore feces sink, but if we assume (conservatively) that they have a density equal to that of water, an $A$. glaucoparieus ingests feces with a wet weight equal to about $3-5 \%$ of its own body wet-weight during a spawning period, while an $N$. vlamingii ingests material equal to about $20-25 \%$ of its own wet-weight over the same time span.

\section{DISCUSSION}

Coprophagy is widespread among herbivorous, detritivorous, and - to a lesser extent - carnivorous fishes at Palau. All of the herbivorous and detritivorous fishes observed for substantial amounts of time ate fresh fish feces. Coprophagic fishes ate large amounts of the feces produced by a variety of fishes belonging to several major trophic groups. In many instances coprophagy was evidently fortuitous. Fishes of many types seemed to monitor the local situation by observing, and often approaching, some types of potential producers. However, a few species regularly associated with local concentrations of certain fishes. These latter fishes produced high-quality feces (Bailey and Robertson, unpubl.). Two of those species consumed such large quantities of feces that fish feces must have been an important component of their diets. The dietary importance of feces for individuals of other reef fishes remains to be determined.

The major trophic groups had the following ranking in terms of the amounts of their feces eaten by fishes: zooplanktivores and (probably) other carnivores > microalgivores and corallivores with LCDs > macroalgivores with LCDs $>$ herbivores with HCDs. The general direction of flow of fecal material in the food chain of coprophagic fishes paralleled this ranking, although material also commonly moved directly from the highest ranking group to the lowest.

Bailey and Robertson (unpubl.) have analysed the rectal contents of 3 Palauan fishes whose feces were commonly eaten (a zooplanktivorous damselfish, a corallivorous chaetodon with an LCD, and a herbivorous surgeonfish with an LCD of microalgae). The protein and lipid content of such material equals or exceeds the protein and lipid content of various fleshy algae, including types eaten by herbivorous fishes. The rectal contents of an HCD parrotfish, whose feces were not eaten, contain very little of those potential food materials. Thus, some feces have potential food 
value. 'High-quality' feces may be as good as or better than algae as an energy source. Fishes have dietary requirements for a variety of amino acids (e. g. Phillips, 1969; Conway and Sargent, 1979) and protein requirements higher than other vertebrates (e. g. Love, 1970). Omnivorous fishes often require animal material in their diets (Menzel, 1959; Fischer, 1972, 1973) and individual diet components are absorbed more efficiently when the fish has a mixed diet (Kitchell and Wendell, 1970; Fischer, 1973; Mathavan et al., 1976).

The unidirectional movement of fecal material from carnivores into herbivores, and from LCD microalgivores and corallivores into LCD macroalgivores and HCD herbivores probably reflects differences in the food value of the different feces. First, animal tissue generally is more digestible by fishes than is plant tissue. Animal tissue contains much more protein and lipid and much less structural carbohydrate than plant tissue; fishes can digest and utilize protein and lipid more efficiently than carbohydrate, and can assimilate animal protein and lipid more efficiently than plant protein and lipid (Kapoor et al., 1975; Brett and Groves, 1979; Montgomery and Gerking, 1980). If the composition of the feces of the 4 species dealt with by Bailey and Robertson (unpubl.) is a reasonable general indication of feces quality in each trophic group, then carnivore feces has greater food value than does herbivore and corallivore feces. Second, the types of algae eaten by LCD microalgivores, fleshy red and green algae, a p pare $n t l y$ are more digestible by fish than are brown algae such as those that LCD macroalgivores eat (Montgomery and Gerking, 1980), and herbivorous fishes generally seem to prefer the former types of algae over the latter (Lassuy, 1980; Montgomery, 1980; Montgomery et al., 1980). The high carbonate level in feces of $\mathrm{HCD}$ herbivores presumably makes these among the lowest quality of any fish feces. Further, coprophagic interactions between species in the same trophic group are not common, and autocoprophagy and intraspecific coprophagy virtually never occur. These absences probably reflect both similarities in digestive capabilities of members of the same trophic group and the apparent lack by herbivorous fish of a generally present gut flora that could aid digestion by degrading carbohydrates (Sera et al., 1974; Fange and Grove, 1979) and that might alter the potential food value of fecal material. A lack of intraspecific coprophagy might also reduce the risks of transfer of some types of parasites.

The food value of a feces, which reflects the defecator's diet and digestive abilities, is not the only determinant of whether its feces is likely to be eaten. Various aspects of the natural history and behavior of both defecators and coprophages interact and affect the chance that a particular feces will be eaten:
(1) The time a feces spends in the water column, which will depend upon its density and height of release, affects the chance that it will be eaten. Zooplanktivore feces, which are commonly eaten, take a long time to reach the substrate because they are of low density and are released well above the bottom. Non-detritivorous fishes did not take a feces from the substrate except just after it reached the bottom. Although detritivorous fishes may pick up parts of a feces sometime after it reached the sea bottom, such behavior is very difficult to detect and its importance is difficult to evaluate. The chance that a desirable feces will be eaten by a fish is reduced once the feces reaches the bottom, because (a) the feces may disappear down a crevice; (b) it may be broken up and dissipated by wave surge; (c) it also becomes accessible to other coprophages, e. g. bottom-living invertebrates; and (d) fish might be more inclined to ingest a freshly produced feces than a slightly older one from which usable material has leached out and which has not been enriched by bacterial growth.

(2) Small size may reduce a feces' chance of being eaten; the rates of consumption of feces of dussumierids feeding on fish eggs and of feces of the small surgeonfish Acanthurus nigrofuscus were much lower than rates of consumption of feces of similar but larger species. A small feces probably is more difficult to detect than a large one and its consumption offers a lower return for effort than the consumption of a large one.

(3) Feces consistency varies within and between species. A fragmentary feces presumably is harder to detect and identify than a cohesive one. This may explain why fewer fragmentary feces than cohesive feces of one zooplanktivore were eaten by fishes.

(4) The tendency for some species to behave in a specific and characteristic manner immediately prior to and during defecation enables coprophages to predict defecation and facilitates coprophagy.

(5) Social facilitation of defecation, which occurs in pairs of at least one corrallivorous chaetodon, may facilitate coprophagy through coprophage learning.

(6) The general activity of a particular type of defecator at the time of defecation probably has a strong effect on the chance that its feces will be eaten. The high rate of production of feces by zooplanktivores when they are feeding in the water column increases the exposure of their feces to coprophages. Conversely, the tendency for some benthic-feeding fishes to defecate above the bottom when not feeding increases the chance that their feces will be consumed.

(7) Interspecific territoriality by a species that strongly attacks coprophages might be expected to reduce consumption of feces of the territorial species. Such inhibition would be strongest when the species' 
territories were aggregated. This may explain, in part, why coprophages eat fewer feces of Acanthurus lineatus, which formed 'colonies', than of A. glaucoparieus, whose territories were more dispersed (Robertson, unpubl.). Strong territoriality and clumping of territories may have contributed to the low rate of consumption of feces of several damselfishes (Eupomacentrus lividus, E. nigricans, and Plectroglyphidodon dickii). A local scarcity of coprophages could be due to the aggregation of territories of a highly territorial species or to a lack of alternate foods or other resources. The territorial damselfish $P$. dickii lives in large beds of living corals in which few other herbivorous and detritivorous fishes occur. A scarcity of coprophages for reasons other than the territoriality of this damselfish probably contributed to the low rate of ingestion of its feces. Conversely, the tendency of planktivores to be non-territorial and to aggregate when producing feces probably facilitates coprophagy of their feces. Their feces are concentrated in a small part of the water column and they do not interfere with the coprophages' activity.

(8) The extent to which 2 groups of species engaged in coprophagy at particular times may depend on the availability of other foods, particularly the precursors of the feces consumed. While zooplanktivorous fishes sometimes fed on the feces of other zooplanktivores, at other times they ignored such feces. One might expect that such coprophagy would occur when little plankton was available to the coprophages. Overall, the main factor besides food value that determines the chance that a particular feces will be eaten is the accessibility of that feces to coprophages. Zooplanktivore feces usually are eaten because they have high food value and are highly accessible. Variation in the likelihood of consumption of feces of different LCD microalgivores and corallivores probably reflects variation in accessiblity much more than variation in food value. However, general differences in the frequency of consumption of feces at the level of major trophic groups of herbivores and detritivores reflect consistent differences in food value of feces much more than they do differences in accessibility. Parrotfish feces were as accessible as those of Acanthurus glaucoparieus, but only those of the latter were eaten.

Because coprophagy is so widespread, and because coprophages often eat feces of other coprophages that occupy a higher position in this food web, the fish 'community' tends to act as a 'food trap' and to retain material that enters it. Much of the zooplanktonic material that is eaten at the outer edge of the reef may pass through the digestive tracts of 3 species of fishes before (any?) solid material reaches the sea bottom. The few data available show that the excreta of piscivorous fishes are eaten by herbivorous fishes. These support the idea that the fish 'community' recycles food.

Animal food material from outside reef fish communities moves directly into those communities through 2 main routes: First, zooplankton in the mass of water that flows from the ocean over a reef is captured by resident diurnal zooplanktivores. Second, a group of species that rest on reefs during the day move into surrounding seagrass beds at night to feed on benthic invertebrates. The relative abundance of those 2 trophic groups of fishes can vary considerably between reefs (Gladfelter et al., 1980). At the Palau study site, diurnal zooplanktivores were very abundant, while nocturnal benthic-feeders were relatively uncommon (own obs.). In many reefs in the Caribbean the converse is true (Gladfelter et al., 1980; own obs.). Observations that I have made off the Caribbean coast of Panama, on reefs in which nocturnal benthic-feeders are abundant, indicate that many fishes there are coprophagic and that, qualitatively, coprophagic relations there are the same as at Palau. Feces that nocturnal benthic-feeding grunts (Pomadasyidae) produce during the day while at rest in aggregations on those Panama reefs are readily eaten by herbivorous reef fishes. It would be useful to determine how much of the feces of those fishes is channeled into and retained by the fish communities on those reefs in the same way that feces of diurnal zooplanktivores was absorbed by the fish 'community' at Palau.

There are at least 3 general reasons why coprophages eat feces rather than its precursor. First, morphological limitations may often preclude a coprophage from efficiently collecting the precursor. For example, parrotfishes may eat feces of corrallivorous chaetodons rather than live coral because they cannot remove the thin layer of coral tissue without also ingesting large amounts of coral skeleton. The surgeonfish Ctenochaetus striatus has a suctorial mouth (with soft brushlike teeth) that apparently precludes it from actively cropping attached benthic microalgae (Randall, 1980) and limits it to ingesting detritus, sediment and fish feces, including feces of the LCD microalgivores with which it overlaps spatially. Second, in a number of cases the defecator actively defends the feces-precursor against coprophages. The best examples of such activity occur among the LCD consumers of microalgae. Territorial damselfishes and surgeonfishes, such as Acanthurus lineatus and A. glaucoparieus, vigorously exclude from their feeding areas other LCD microalgivores, LCD macroalgivores and HCD herbivorous parrotfishes that eat those territorial species' feces. Third, it is conceivable that the process of digestion by the defecator alters the quality of the precursor and renders it more usable to the coprophage. 
Given that fish feces have food value, I suggest that the widespread occurrence of coprophagy among Palauan fishes indicates that the other foods available are insufficient in quantity or quality for individual fishes to be able to maximize their growth and reproductive outputs through their use alone. This food limitation seems to be particularly evident among herbivorous fishes, including both species that are highly territorial and defend feeding areas against a large range of other fishes (e.g. Acanthurus lineatus, A. glaucoparieus, certain damselfishes), as well as the species that territorial fishes exclude from their feeding areas. Intermittent food limitation also evidently affects species of zooplanktivores which remain closest to the substrate and which may be outcompeted for planktonic food by species that feed further from the substrate.

Coral reefs offer a combination of conditions which greatly facilitate coprophagic interactions among vertebrates: First, coprophages have the best chance of locating a feces and identifying its producer when the producer cruises above the substrate away from visual obstructions in the clear waters of a reef. Second, coprophages can move freely through the water and intercept feces before they reach the substrate. Third, because of water's high density, feces spend a long time in transit to the substrate. Thus, in a clear-water environment, feces stand the best chance of being detected, identified and intercepted before they reach the sea bottom. Fourth, coral reef fish communities are characterized by a high diversity of species and of trophic groups, on both large and small spatial scales, and by high population densities (Smith and Tyler, 1973; Hobson, 1974; Jones and Chase, 1975; Goldman and Talbot, 1976; Sale, 1977; Luckhurst and Luckhurst, 1978; Gladfelter et al., 1980). In such systems there is a high chance that, when a feces is released, a coprophage of the 'right' type will be in the immediate vicinity. Such 'fortuitous' coprophagy can account for large amounts of edible feces when cost/benefit considerations preclude the association of coprophages with fishes that produce high-quality feces at low rates.

Finally, the widespread occurrence of coprophagy by many fishes of different trophic groups needs to be taken into account in at least 2 aspects of reef fish ecology. First, determination of diets by gut content analysis, which is common practice in studies of reef fishes (e. g. Hiatt and Strasburg, 1960; Randall, 1967; Hobson, 1974, 1975; Hobson and Chess, 1978) may be inadequate. Feces in the stomach contents of fishes may be unrecognizable. If the fecal material is recognizable it may give a quite false picture of the origin of the fish's food and of its position in the food web. Second, as has been previously recognized (Laird,
1961; Frankenberg and Smith, 1967), coprophagic relationships could readily be exploited by parasites to affect transfer from one host to another.

Acknowledgements. S. Foster assisted in the field work. S. Garrity, H. A. Lessios, and A. S. Rand criticized drafts of the manuscript. J. E. Randall and G. R. Allen provided taxonomic information on certain fishes. I thank Noah Idechong of the Micronesian Mariculture Demonstration Center, Koror, Palau, and William Hammner for their assistance throughout the project. This work was financially supported by the Smithsonian Institution and by the M.M.D.C

\section{LITERATURE CITED}

Allen, G. R. (1975). Damselfishes of the South Seas, TFH, Neptune City, New Jersey

Allen, G. R. (1979). Butterfly and angelfishes of the world, Vol. 2, Wiley, New York

Bardach, J. E. (1961). Transport of calcareous fragments by reef fishes. Science, N.Y. 133: 98-99

Barlow, G. W. (1975). On the sociobiology of four Puerto Rican parrotfishes (Scaridae). Mar. Biol. 33: 281-293

Brett, J. R., Groves, T. D. D. (1979). Physiological energetics. In: Hoar, W S., Randall, D. J., Brett, J, R. (eds.) Fish physiology, Vol. 8. Academic Press, New York, pp. $279-352$

Cloud, P. E., Jr. (1959). Geology of Saipan, Mariana Islands, Part 4, Submarine topography and shoal-water ecology. US Dept. Int. Geol. Survey Prof. Pap. 280-K: 361-445

Cowey, C. B., Sargent, J. R. (1979). Nutrition. In: Hoar, W. S., Randall, D. J., Brett, J. R. (eds.) Fish physiology, Vol. 8. Academic Press, New York, pp. 1-69

Fänge, R., Grove, D. (1979). Digestion. In: Hoar, W. S., Randall, D. J., Brett, J. R. (eds.) Fish physiology, Vol. 8. Acadernic Press, New York, pp. 162-260

Fischer, Z. (1972). The elements of energy balance in grass carp (Ctenopharyngodon idella Val.). Part 3. Assimilability of proteins, carbohydrates, and lipids by fish fed with plant and animal food. Pol. Arch. Hydrobiol. 19: 83-95

Fischer, Z. (1973). Physiology and bioenergetics of grass carp. Pol. Arch. Hydrobiol. 20: 521-557

Fowler, H. W. (1959). Fishes of Fiji, Govt. Fiji, Suva

Frankenberg, D., Coles, S. L., Johannes, R. E. (1967). The potential trophic significance of Callianassa major fecal pellets. Limnol. Oceanogr 12: 113-120

Frankenberg, D., Smith, K. L., Jr. (1967). Coprophagy in marine animals. Limnol. Oceanogr. 12: 443-450

Frydl, P., Stearn, C. W. (1978). Rate of bioerosion by parrotfish in Barbados reef environments. J. Sed. Petrol. 48: $1149-1158$

Gladfelter, W. B., Ogden, J C., Gladfelter, E. H. (1980). Similarity and diversity among coral reef fish communities: a comparison between tropical western Atlantic (Virgin Islands) and tropical central Pacific (Marshall Islands) patch reefs. Ecology $61: 1156-1168$

Glynn, P. W., Stewart, R. H., McCosker, J. E. (1972). Pacific coral reefs of Panama: structure, distribution and predators. Geol. Rundschau 61: 483-519

Goldman, B., Talbot, F. H. (1976). Aspects of the ecology of coral reef fishes. In: Jones, O. A., Endean, R. (eds.) The biology and geology of coral reefs, Vol. III, Biology 2. Academic Press, New York, pp. 125-154

Helfrich, P., Piyakarnchana, T., Miles, P. S. (1968). Ciguatera 
fish poisoning. I. The ecology of ciguateric reef fishes in the Line Islands. Occ. pap. Bishop Mus. 23: 305-382

Hiatt, R. W., Strasburg, D. W. (1960). Ecological relationships of the fish fauna on coral reefs of the Marshall Islands. Ecol. Monogr 30: 65-127

Hobson, E. S. (1974). Feeding relationships of teleostean fishes on coral reefs in Kona, Hawaii. Fish Bull. U.S. 72: 915-1031

Hobson, E. S. (1975). Feeding patterns among tropical reef fishes. Am. Scient. 63: 382-392

Hobson, E. S., Chess, J. R. (1978). Trophic relationships among fishes and plankton in the lagoon at Enewetak Atoll, Marshall Islands. Fish. Bull. U.S. 76: 133-153

Johannes, R. E., Satomi, M. (1966). Composition and nutritive value of faecal pellets of a marine crustacean. Limnol. Oceanogr. 11: 191-197

Jones, R. S. (1968). Ecological relationships in Hawaiian and Johnston Island Acanthuridae (surgeonfishes). Micronesica 4 : 309-361

Jones, R. S., Chase, J. A. (1975). Community structure and distribution of fishes in an enclosed high island lagoon in Guam. Micronesica 11: 127-148

Kapoor, B. G., Smit, H., Verighina, I. A. (1975). The alimentary canal and digestion in teleosts. Adv. mar. Biol. 13: 109-239

Kitchell, J. F., Windell, J. T. (1970). Nutritional value of algae to bluegill sunfish Lepomis macrochirus. Copeia 1970: $186-190$

Laird, M. (1961). Microecological factors in oyster epizootics. Can. J. Zool. 39: 449-485

Lassuy, D. R. (1980). Effects of farming behavior by Eupomacentrus lividus and Hemiglyphidodon plagiometopon on algal community structure. Bull. mar. Sci. 30: $304-312$

Lobel, P. S. (1980). Herbivory by damselfishes and their role in coral reef community ecology. Bull. mar Sci. 30: 273-289

Love, R. M. (1970). The chemical biology of fishes, Academic Press, New York

Luckhurst, B. E., Luckhurst, K. (1978). Analysis of the influence of substrate variables on coral reef fish communities. Mar. Biol. 49: 317-323

Mathavan, S. E., Vivekanadan, Pandian, T J. (1976). Food utilization in the fish Tilapia mossambica fed on plant and animal foods. Helgoländer wiss. Meeresunters. 28: 66-70

Menzel, D. W. (1959). Utilization of algae for growth by the angelfish, Holocanthus bermudensis. J. Cons. perm. int. Explor. Mer. 24: 308-313

Montgomery, W. L. (1980). Comparative feeding ecology of two herbivorous damselfishes (Pomacentridae: Teleostei) from the Gulf of California, Mexico. J. exp. mar. Biol. Ecol. 47: $9-24$

Montgomery, W. L., Gerking, S. D. (1980). Marine macroalgae as foods for fishes: an evaluation of potential food quality. Env. biol. Fish. 5: 143-153

Montgomery, W. L., Gerodette, T., Marshall, L. D. (1980). Effects of grazing by the yellowtail surgeonfish, Prionurus punctatus, on algal communities in the Gulf of California, Mexico. Bull. mar. Sci. 30: 901-908

Moyer, J. T., Nakazono, A. (1978). Population structure, reproductive behavior and protogynous hermaphroditism in the angelfish Centropyge interruptus at Miyakejima, Japan. Jap. J. Ichthyol. 25: 25-39

Munro, I. S. (1967). The fishes of New Guinea, Dept. Agric. Stock Fisheries, Port Moresby, Niugini

Ogden, J. C. (1977). Carbonate-sediment production by parrotfish and sea urchins on Caribbean reefs. Studies in Geology 4: 281-288

Phillips, A. M., Jr. (1969). Nutrition, digestion, and energy utilization. In: Hoar, W. S., Randall, D. J. (eds.) Fish physiology. Academic Press, New York, pp. 391-432

Randall, J. E. (1955). Fishes of the Gilbert Islands. Atoll Res. Bull. 47: 1-243

Randall, J. E. (1967). Food habits of reef fishes of the West Indies. Stud. trop. Oceanogr. 5: 665-847

Randall, J. E. (1980). A survey of ciguatera at Enewetak and Bikini, Marshall Islands, with notes on the systematics and food habits of ciguatoxic fishes. Fish. Bull. U.S. 78 : 201-249

Randall, J. E., Brock, V E. (1960). Observations on the ecology of epinepheline and lutjanid fishes of the Society Islands, with emphasis on foods habits. Trans. Am. Fish. Soc. 89: 9-16

Randall, J. E., Klausewitz, W. (1973). A review of the triggerfish genus Melichthys, with descriptions of a new species from the Indian Ocean. Sencken. biol. 54: 57-69

Reese, E. S. (1975). A comparative field study of the social behavior and related ecology of reef fishes of the family Chaetodontidae. Z. Tierpsychol. 37: 37-61

Sale, P. F. (1977). Maintenance of high diversity in coral reef fish communities. Am. Nat. 111: 337-359

Scoffin, T. P., Stearn, C. W., Boucher, D., Frydl, P., Haskins, C. M., Hunter, I. C., MacGeachy, J. K. (1980). Calcium carbonate budget of a fringing reef on the west coast of Barbados, Part II. Erosion, sediments and internal structure. Bull. mar Sci. 80: 475-508

Sera, H., Ishida, Y., Kadota, H. (1974). Bacterial flora in the digestive tracts of marine fish. In: Cobwell, R. R., Moreta, R. Y (eds.) Effect of the ocean environment on microbial activities. Unversity Park Press, Baltimore, Maryland, pp. $467-490$

Smith, C. L., Tyler, J. C. (1973). Population ecology of a Bahamian suprabenthic shore fish assemblage. Am. Mus. Novit. 2528: 1-38

Smith, R. L., Paulson, A. C. (1974). Food transit times and gut $\mathrm{pH}$ in two Pacific parrotfishes. Copeia 1974: 796-799 